\title{
EQUiLIBRIUM
}

Quarterly Journal of Economics and Economic Policy

2014 VOLUME 9 ISSUE 4, December

p-ISSN 1689-765X, e-ISSN 2353-3293

www.economic-policy.pl

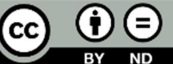

Ząbkowicz, A. (2014). Institutional Interests and Institutional Change. Poland on the Second Wave of Pension Reforms. Equilibrium. Quarterly Journal of Economics and Economic Policy, 9(3), pp. 47-64, DOI: $\underline{\text { http://dx.doi.org/10.12775/EQUIL.2014.024 }}$

Anna Ząbkowicz*

Jagiellonian University, Poland

\section{Institutional Interests and Institutional Change. Poland on the Second Wave of Pension Reforms}

\section{JEL Classification: $B 52 ; P 16$}

Keywords: capital funded pension schemes; open pension funds; pension reform engineering; political economy of pension reforms in Poland

\begin{abstract}
The paper discusses mandatory funded pensions seen as a novelty of the first wave of "paradigmatic" pension reforms in emerging market economies and as an institutional device in the very centre of the recent post-2008 change. Evidence from Poland is examined in the context of the pension reform engineering. The central question is for whose welfare or benefit the open pension funds (OFEs) were introduced and why they have been scaled down recently. The perspective taken here is to explain the processes through reconstruction of major interests involved. Under the assumption that the state is the main force at play, the economic and political interests of this party are reconstructed and discussed. The proposition that rising deficits and debts within general government sector provided stimuli for both rise and decline of the OFEs is the very start of the diagnosis. The paper argues that apart from the undesirable outcome of current debt accounting there were fundamental reasons of strategic nature for which government lost its positive interest in the OFEs as an institutional (that is long-run) device.
\end{abstract}

(C) Copyright Institute of Economic Research \& Polish Economic Society Branch in Torun

Date of submission: September 19, 2014; date of acceptance: October 7, 2014

* Contact: anna.zabkowicz@uj.edu.pl, Uniwersytet Jagielloński, WZiKS, ul. Łojasiewicza 4, 30-348 Kraków, Poland 


\section{Introduction}

Over the course of the 1990s a number of middle-income countries introduced a novelty into their pension systems, which was mandatory funded pillar. In Poland it meant introduction of an utterly new regime aside of financing on PAYG basis. Capital funded pension schemes ${ }^{1}$ introduced financial logic to where principle of social insurance had ruled. They created new business opportunities for private companies in the traditionally public domain. This new area of activity of private financial agents was supplied by state's enforcement with respect to fund raising since governments mandate individuals to participate in the funded pension schemes. The post-2008 financial crisis triggered a policy reversal in this respect. The second wave of reforms in Poland has focused on down-scaling mandatory funded pension schemes along with cutting down transfers to this pillar from the general government.

Mandatory funded pensions are examined here according to evidence from Poland. This institutional arrangement seems to focus major paths of the first wave of pension reforms, and its decline is in the centre of the second post-2008 wave. The central question is for whose welfare or benefit were the open pension funds (OFEs) introduced and why they have been scaled down recently. There are three parties at least involved in rise and decline of mandatory pension funds (called OFEs in Poland): the state as an agent of enforcement, would-be pensioners as contributors and financial companies as actual investors of funds. Under the assumption that the state is the major player, economic and political interests of this party are reconstructed and discussed. The question how the rise of OFEs and the later turnabout affected the economic interests of other parties has been left for further research. For reasons of space the paper deliberately ignores other group interests involved like labour unions and employers representations, representations of finance industry, regulators and official supervisors as well as external pressures.

\section{Methods and Contents of the Article}

In the research the approach of institutional and political economy has been applied. The perspective taken here is to explain processes through reconstruction of major interests involved. The leading question is: for whose sake were the reforms introduced and why were they reversed? Asking this,

\footnotetext{
${ }^{1}$ Funded pensions use an accumulated fund built from contributions by or on behalf of its participants. Fully-funded pensions pay all of benefits from accumulated funds (Barr \& Diamond, 2009).
} 
the paper focuses on specific institutional arrangement and crucial interests already mentioned.

The method relies on orderly analysis which is founded on a review of the literature relevant to the subject and is carried on as follows. First, the new arrangement is presented in the context of the pension reform engineering in emerging market economies at the turn of the XX and XXI centuries (the next section). Four paths of change are identified, namely a shift in the formula for calculating pensions from Defined Benefit (DB) to Defined Contribution (DC), expansion of capital funded pension schemes, privatization of fund-management and introduction of individual accounts. Next, it is argued that mandatory funded pension schemes seem to focus three of those paths, and regulatory post-1999 framework in Poland in this respect is presented. The same section reports how this set of rules was changed as a result of the 2013-turnabout. The final section discusses rising deficits and debts within general government sector as a crucial stimulus for change in institutional design of the OFEs. It aims to show that policy rationale for institutional change under examination contained inter alia the solution to implicit-pension-debt problem as well as stimuli for economic growth (and for consequent budget revenues) via development of financial markets.

\section{What were the pension reforms about?}

Talking about pension reforms considers two waves of major change: at turn of the millenium and in 2008 and beyond. The first wave refers to deep, "paradigmatic" reforms in the less developed countries, and to the socalled "parametric" reforms of pension systems in the developed market economies in Europe which did not radically change the paradigm of oldage income security.

During the 1990s and early 2000s a variety of pension reforms was introduced in a number of Latin American as well as Eastern European economies under transition. As the International Labour Organization reports (Sarfati \& Ghellab, 2012, p. 15) "[f]ollowing the Chilean reform, 11 more countries in Latin America included mandatory savings tiers in their pension systems. The first wave of such systemic paradigmatic reforms in Latin America was followed by reforms in 13 countries in Central and Eastern Europe and Central Asia: Bulgaria, Croatia, Estonia, Hungary, Kazakhstan, Latvia, Lithuania, the former Yugoslav Republic of Macedonia, Poland, Romania, Russian Federation, Slovakia and Ukraine. These countries implemented multi-tier systems that were essentially scaled-down versions of the Latin American reforms." Then the report states that "[t]he crisis of 
2008 and beyond has led to new developments in the history of pension reform." Some Latin American countries have either effectively reversed their reforms (Argentina, Bolivia) or accommodated them by transfers of public money (Chile, noncontributory universal pension). In a substantial number of Central and Eastern-European countries new wave of reforms meant the down-scaling of the private tier of their pension systems (e.g. Poland), even up to extinction of open pension funds (Hungary).

In order to make clear what the reforms were about and what idea of mandatory savings tiers meant, in fact, basic information on pension system engineering must be introduced. The core idea of designing pensions is security which is provided by an income (pension) to be paid to a person when in the retirement age. This income can be secured through variety of schemes and plans for employees and/or citizens. These can be in essence savings plans like Singapore's publicly administered provident fund. These can be also public noncontributory funds where a universal pension is based on years of residence (Barr \& Diamond, 2009, p. 2). However, the most widespread scheme for financing pensions, in Europe and Americas at least, is insurance where a benefit is conditioned on a contribution.

Since Bismarck's and Beveridge's times the state became involved in the pension schemes with its power to impose either taxes or contributions, and the funds raised were traditionally managed by state's agencies in order to benefit retired people. Since then a core financing of pensions is carried out on mandatory basis. In some countries, state guarantees of minimal amount of pension were introduced.

As far as old-age-insurance concerned the financing can be founded on current contributions (Pay-as-you-go pensions) or on accumulated funds (Funded pensions). Pay-as-you-go (PAYG) pensions are paid out of current revenue that comes, basically, from contributions to the system made by the actually employed (the would-be-pensioners). Funded pensions are financed from investment outcomes of funds accumulated due to contributions of or on behalf of their participants, and no redistribution between current contributors and current beneficiaries is in place. Usually, a mix of public PAYG and funded systems is in operation. According to Barr and Diamond's record $(2009$, p. 16), there are systems with substantial reliance on funding (Chile, Sweden), others with intermediate reliance on funding (the United States), and others operating mainly on a PAYG basis (France, Germany, Italy).

The basic relation in insurance industry is the one between contribution and benefit, which can be designed in two different ways. According to defined-benefit (DB) formula the benefit does not directly depend on the amount of assets accumulated on behalf of a person. The formula may be based on the worker's wages that is on final wage and length of service, or 
on wages over a longer period under the course of the worker's career. It indicates liabilities with respect to the person retired, and funds are adjusted to meet these liabilities. In effect, the risk of varying rates of return to pension assets falls on the sponsor, that is normally on the state budget. Such rules have been recently maintained in some European countries (Switzerland, Netherlands, Iceland) (Impavido \& Tower, 2009, p. 12). Definedcontribution (DC) plan seems to be a reverse to DB scheme in the sense it adjusts liabilities to match available funds. Namely, the benefit is determined by the amount of assets accumulated toward a person's pension. Thus, this is an individual participant of the scheme to face the investment risk.

With concern to the risk that arises due to varying rates of return on pension assets the schemes may be enriched by arrangements that increase their accountability. Personal records when introduced into PAYG segment improve accountability in the sense they enable counting pension debt and make liabilities of the system to would-be pensioners explicit (Rutecka, 2014, p. 5). It is possible to have funding without individual accounts, for example through a central trust fund, like in Sweden or Canada. However, in some societies the old-age insurance system may be considered more liable if pension savings are recorded on personal accounts.

Having these options in mind, one becomes convinced that there is no universal design for pension schemes. Multiple combinations can be made as far as formula of calculation (DB pensions/DC pensions) and financing (PAYG/funded/partially funded) as well as recording (central trust/individual accounts) concerned. Nicholas Barr argues that this peculiar engineering must not ignore the level of socio-economic development. There is no universal receipt; different combinations suit best the low-income, medium-income and high-income countries. Social development, values and preferences constitute additional variables in this "modeling" on different levels of income.

Public choices concerning the new in pension industry have revealed, however, quite clear trends. The 1990s and early 2000s have seen reforms which drive old-age insurance systems along four rather distinct paths. The first major change refers to formula for calculating pensions. There has been a mass shift from DB rule to DC formula. This obviously means a relief to insurers by shifting the consequences of varying rates of return on pension assets away from insurer to the insured individuals.

Another trend observed refers to the mode of financing. Last decades have seen an expansion of funded pension schemes. To be more precise, they have been extended in the developed countries where they had already operated on voluntary basis, and they have been developed "green field" in the countries under transition. The "parametric" reforms in developed coun- 
tries promoted voluntary old-age insurance through tax privileges and friendly regulation. The less developed countries mentioned above, however, restructured their pension sectors fundamentally. Transition economies of Eastern Europe introduced voluntary funded schemes which were hardly new in the developed countries of Europe and North America. Moreover, open pension funds emerged due to transfers of a portion of contribution collected by state agency to private managing firms.

Since funding is normally managed by private companies, this change means advance in privatisation of the pension industry. In countries which introduced mandatory funded pensions financial companies engaged in open pension funds could enjoy contributions being enforced by the state apparatus. Thus the states have invited private firms into the area which traditionally was a domain of state compulsion and was managed by public agencies.

Finally, rising popularity of individual accounts can be counted as the fourth path of the reform. Thus the basic change in effect of early pension reforms consisted in:

- shifting from Defined Benefit formula to Defined Contribution or Notional Defined Contribution (NDC) formula

- introducing pension funding (mandatory funding included)

- introducing individual financial accounts in public pension insurance

- privatisation of the pension industry

\section{Institutional design of mandatory funded pensions in Poland}

Accordingly, in result of pension reform of 1999 in Poland there was a shift from Defined Benefit formula to Notional Defined Contribution (NDC) formula which means a person's pension bearing a quasi-actuarial relationship to his or her lifetime pension contributions with pensions financed on a pay-as-you-go or/and funded basis (Barr \& Diamond, 2009). Introduction of the new formula which meant inter alia that public funds are no more to be adjusted to meet liabilities was of core significance to the reduction of public pension system deficit. On the other hand, it caused an average benefit related to average wage to decrease dramatically. In the face of this political problem introduction of funding might be presented to the voters as a novelty in financing pensions which brings "security due to diversity" (UNFE, 2000). Then, since 1999 a contribution to mandatory pension insurance used to be divided between the publicly managed pension fund FUS and one of the privately managed open pension funds (OFEs). Apart of mandatory contributions to open pension funds a voluntary old-age in- 
surance has been allowed, which makes separate funds (PPEs, IKE/IKZEs). Table 1 presents the "three-pillar" structure of the pension industry in Poland that resulted from the reform. In sum, the Polish government while maintaining the pillar financed on participatory basis (PAYG) supported pensions funded both on voluntary and mandatory basis. Funding became fully privatised in the sense of management. The OFEs are managed by licensed companies named Powszechne Towarzystwa Emerytalne (PTEs). These were established by a number of banks and insurers, most of them being foreign subsidiaries. The employers' pension schemes (PPEs) as well as pension funds made of voluntary contributions (IKE/IKZEs) are managed by private companies (TFIs) as well. Finally, after the reform information on liabilities within the system is stored on individual financial accounts.

Table 1. Old-age insurance in Poland as outcome of the reform of 1999

\begin{tabular}{|c|c|c|c|}
\hline Pillar & I & II & III \\
\hline \multirow{2}{*}{$\begin{array}{l}\text { contribution (as } \\
\text { percentage of wage) }\end{array}$} & 12,22 & $7,30 *$ & as contracted \\
\hline & \multicolumn{2}{|c|}{ mandatory } & voluntary \\
\hline \multirow[t]{3}{*}{ funds } & FUS (reformed) & OFE & PPE, IKE/IKZE \\
\hline & $\begin{array}{l}\text { individual accounts, } \\
\text { official valorization }\end{array}$ & $\begin{array}{l}\text { individual accounts, } \\
\text { financial investment } \\
\text { yield } \\
\end{array}$ & $\begin{array}{c}\text { individual accounts, } \\
\text { financial investment } \\
\text { yield } \\
\end{array}$ \\
\hline & \multicolumn{3}{|c|}{ Notional Defined Contribution (NDC) } \\
\hline management & Public agency - ZUS & $\begin{array}{c}\text { Private companies - } \\
\text { PTE }\end{array}$ & $\begin{array}{c}\text { Private companies - } \\
\text { TFI }\end{array}$ \\
\hline financing & $\begin{array}{l}\text { Pay-as-you-go } \\
\text { (PAYG) }\end{array}$ & Fully funded & Fully funded \\
\hline \multirow[t]{2}{*}{ pensions } & ZUS & ZUS** & \\
\hline & & premium \\
\hline
\end{tabular}

* The share was reduced to $3,5 \%$ in $2011 \mathrm{r}$. and to $2,92 \%$ in 2013 .

**According to the law of 2013 ZUS is in charge of paying out the annuities from both pillars.

Source: developed by the author.

Mandatory funded pillar ("the second pillar") is linked to the public agency managing the PAYG ("the first pillar") in two ways. Namely, ZUS collects contributions and makes transfers in due portions to the OFEs. However, the agency is not in power to supervise the OFEs' segment which used to be under control of a specialized bureau UNFE and now is under supervision of the financial sector regulator KNF.

The OFEs' segment has consisted of ca 16 million participants on obligatory basis which makes it central for pension funding in Poland whereas funded voluntary pension plans count 1.65 million participants in PPEs and IKE/IKZE. The "market" consists of 14 open pension funds (number re- 
duced from 17 in result of mergers and acquisitions), with 3 of them holding assets that make nearly 60 percentage share (Oręziak, 2014, p. 291, Table 9).

The participants in the segment have been charged three kinds of fees: "transaction cost-covering" fee, "transfer-costs" fee and "administrative commission" due for fund-management. The first fee is a percentage of a monthly participant's contribution set at extremely high level of $10 \%$ at the start which even after several reductions (from 7\% in 1999-2009 to recent $1.75 \%$ ) still remains high by international standards ${ }^{2}$. Due to these generous fees allowed by law the PTEs seemed not to be subject to stringent calculus of operational costs. Those were costs of marketing campaigns with army of agents engaged (450 thousand at the peak) as well as wages of PTEs' employees with wages of executives reaching a 13-fold of an average in Poland. So called transfer fee was to be paid by a member whenever he or she shifted between the OFEs, which was a punishment for non-loyal customer in fact (recently abolished). And finally, management commission was set as a percentage of assets accumulated by the OFE ranging from $0,045 \%$ at the start, and between $0,54 \%$ and $0,276 \%$ annum recently. Thus basically fund-managing companies are rewarded proportionately to assets accumulated in the OFEs rather than to profits made on investment. At the end of the day, this is the number of participants in the OFE that matter for the PTEs.

Rewarding and punishment was tied to the very specific reference index. Namely, OFEs were ranked according to the so called rate of return, which measured the dynamics of so called accounting unit in a given time interval. In other words, it showed at the end of a quarter how much the capital valued in accounting units has changed since the beginning of the period. An average rate of return for whole population of OFEs constituted an inner benchmark. Punishment came only when OFE's individual rate of return on assets was lower than the halved average. The rule of the game said that in the event the fund's rate did not reach this minimum the fundmanaging company had to shift their own money to the open pension fund. On the other hand, those OFEs with indices higher than average were rewarded with a premium which was characteristic of "OFE market". Namely, they could expect extra rise in the number of contributors since those young people who made no declaration concerning their choice of OFE would be randomly ordered just to those funds (Pater, 2002). The PTEs did not risk dramatic deterioration in ranking either took no financial risk as

\footnotetext{
${ }^{2}$ In Sweden the fee from open-pension-fund-participants was in average $0.32 \%$ (2010). Retrieved from https://secure.pensionsmyndigheten.se/JamforFonderFondsok.ht $\mathrm{ml}$ ?url=1860026889\%2FSirius\%2FfundSuperSearchUpdateFundList.action\&sv.url=12.70e5 6c27145a7fdc9582ec76.
} 
long as their investment strategies followed those who managed the leading funds. Namely, due to concentration of assets in three largest funds the reference index depended mostly on indices of theirs. Completing similar investment portfolio provided a guarantee for managers of smaller funds that their funds' rates would not differ dramatically from those of the leaders that is from the average. Such arrangement made bankruptcy of a PTE practically impossible once it followed the leaders of the "market", and implied herding in PTEs' investment strategies (MPPS\&MF, 2013, p. 50; Szczurek, 2001).

Thus, the competitive strategy of managing companies instead of innovative investing focused rather on marketing as well as on developing the network of agents useful to acquire new members. The "pool" of customers has been provided automatically by the system since joining one of the OFEs was obligatory ${ }^{3}$, and there was no legal exit from the system. The game among PTEs went on about how this given pool might be distributed between individual OFEs. The less direct way of competing for contributors has led via "rates of return": the more significant increase in the index the more appealing the fund. The direct method was a simple acquisition of smaller OFEs together with their participants, as it happened for instance in the early 2000s. This process of concentration seems to be controversial in the sense it has aggravated oligopolistic bias and made the relation of power between the largest OFEs and their managing companies versus their regulators more uneven. Another way to increase the number of contributors was advertisement campaigns via public media or direct marketing, and individual acquisition activities carried on by commercial agents who used to address participants of other OFEs as well as young people entering labour market when they were about to declare their membership in one of the pension funds. It turned out to be an extremely costly and rather ineffective way.

Such engineering made PTEs' business rather safe with investment risk shifted on to participants in the OFEs. There is no insurance against the loss of assets trusted to OFEs and managed by the PTEs. Due to lack of such protection, the negative consequences of shifting risk to the insured under the DC formula for calculating pensions are even stronger. Participants can see an OFEs' part of their contributions vanishing as it did happen in years of falling security prices, with no compensation from fund-managing companies. In the event when a pension from an open fund added to a pension from PAYG pillar after time of contributing to the system required make a sum below level officially considered to be a minimum Polish state takes

${ }^{3}$ An exception was made at the very start of the reform, and one age-cohort of working population was free not to join the system. 
the financial consequences subsidizing then the pension up to this minimal level (minimum pension guarantee).

However, apart from using state compulsion for the sake of contribution collecting and from using public resources to make guarantees just mentioned, the government put constraints on the investment strategies of the PTEs through a number of strict regulations. Namely, there were ceilings imposed on the shares in the OFEs' portfolios of assets with reference to share-holdings (40\%) and foreign securities (5\%). Moreover, the OFEs were allowed to purchase no more than $10 \%$ of equity of an individual company (Rozłucki, 2001, p. 38).

A breakthrough came with the law of December 2013 (Ustawa 2013). Contributing to OFE is mandatory no more, and those participants who still wish to contribute to an open pension fund can declare only 2,92 of their wage to be transferred to the fund. Thus OFEs find themselves scaled down both in terms of their share in mandatory pension segment and in terms of number of participants. Namely, few are expected to stay with OFE (the deadline for decision-making is end of July 2014) since to accomplish this an active attitude is required whereas commercial agents activities became forbidden. In the event no declaration of insured person has been made his or her contribution remains under management of ZUS, undivided.

As far as accumulated assets concerned the OFEs were scaled down by half due to obligatory transfer of treasury bonds and publicly guaranteed securities from their portfolios to a special account under ZUS management. In result, in early February 2014 the OFEs found assets on their participants' accounts reduced by $51.5 \%$. On the other hand, the Polish government found public debt burden significantly reduced; the ratio of public debt to GDP has been diminished once and for all by 9 percentage points. This has been an accounting effect of course. Once these assets are recorded by ZUS in general government sector, they become invisible to public debt statistics. The rest of accumulated assets, which is shares, mainly remained with OFEs no matter whether pension savers declared "stay" either "exit". It is bound to new investment limits; namely the share-holdings must not be smaller than $75 \%$ of assets in 2014 with yearly limits going to diminish down to $15 \%$ in 2017 . On the contrary, the ceilings put on financial instruments denominated in foreign currencies were raised to $10 \%$ of assets in 2014 and to $20 \%$ of assets in 2015 . Thus, due to the new law the OFEs see their assets dramatically diminished by scale and radically restructured.

From the PTEs' perspective apart from apparent losses also some gains can be seen. They still charge fees due to holding "old" assets in shares no matter whether in 2014 a contributor has declared staying with OFE or not. While maximum fees charged on contributions were reduced to $1,75 \%$ the 
maximum management commission charged on assets remained unchanged. In their investment strategies the PTEs will have to adapt to external bench-marking. In place of internal reference index described above, a soft rule reminding a self-code has been introduced. The very special guaranteed minimal investment yield, which is the average weighted rate of return together with minimal rate of return has vanished. Instead, each PTE is free to point reference indices of their own to be used as a bench-mark to the rates of return of "their" OFE. Hardly for two years, that is up to July 2016, the supervisory agency will be involved in comparing OFEs' everyday individual rates of return with an external bench-mark, which is a mix of stock exchange index and three-month inter-bank interest rate per annum (Rutecka, 2014, p. 3). Last but not least, PTEs enjoy lifted ceilings on financial instruments denominated in foreign currencies mentioned above which they have lobbied for since the very start of the reform (Rozłucki, 2001, p. 38)

The recent policy reversal with respect to mandatory funded pensions must be seen as a struggle to constrain public deficits and debts rather than a battle against privileges of the group interests of the fund-managing financial companies. The OFEs have been not eradicated, and are still handsomely rewarded, and are likely to become far more aggressive investors in capital markets, both in Warsaw and abroad.

\section{Comments on political economy of rise and decline of the OFEs}

For what reasons were the reforms introduced? For what reasons were the reforms reversed? Any policy reform to become effective either to be abolished requires politics and polity. Political decisions are the consequence of procedures and negotiations within broad government. Under this process a political game with social coalitions, both those retarding and those supporting change, must be played.

Mandatory pension funding seems to involve three parties at least: the state, financial companies and pensioners. As a matter of fact government and financial sector are forces at play since would-be pensioners are no organized group of interest and matter solely as voters. Policy-makers' positive interest in reform is rooted in public finance instability, in current illiquidity and implicit insolvency of the pension systems as well in aging of societies. The need for reform seem to have been caught as a chance by representatives of financial sector. The evidence from 1999-2013 in Poland just reported suggests that mandatory funded pensions have been introduced as a result of powerful and organized support of financial interests. 
The outcome of reconfiguration under law of 2013 suggests that they still do effective lobbying for their interests in pension policy. However, regarding the two major players the governmental economic and ideological interests seem to be pivotal as far as dynamics and orientation of reforms are concerned. They constitute the topic here as referred to mandatory pension funding.

From the policy-making perspective, rising deficits and debts within general government sector were undoubtedly relevant rationale for the pension reform in Poland. At the turn of 1999 and 2000 the statistics for Poland revealed significant indices of public debt, pension spending and implicit pension debt (IPD) (Impavido \& Tower, 2009, p. 41). According to the IMF for thirty five low and middle income countries, Poland had 3-rd largest pension spending as share of GDP and 5-th largest IPD as share of GDP (by discount rate $2 \%$ ) with public debt at that time being though relatively moderate (the 16-th position). Soaring public pension deficit and frustrating implicit pension debt required a radical change, and that has been done due to fundamental shift from DB to DC formula in result of the reform of 1999. As one of the members of parliament put it, they voted for the change in aim to diminish the relation between the average pension benefit and the average wage "since coming insolvency of the inter-generational system emerged from utterly all calculations based on demography" ${ }^{4}$ (Łaski, 2010, p. 15). In result, under new pension law a relative benefit in average decreased dramatically; at the turn of the millennium, according to pension system authorities UNFE, a replacement rate was estimated at $63 \%$ for males and $37 \%$ for females (under extremely optimistic assumptions) ${ }^{5}$.

As already mentioned, such policy result needed to be somehow cushioned with regard to the public. Including pension funding into the reform seemed to be of help along with the following rationale attached. Funded pension schemes will possibly increase their part of pension income, improve the sum of benefits originating from different pillars and effectively constrain a further risk of old-age poverty. Investing in capital markets is in the very center of such reasoning. Funds managed by financial firms are to be invested in stock and securities, with return on stock turnover being positive in the long run (Sławiński \& Tymoczko, 2013; Kuczyński, 2011).

\footnotetext{
${ }^{4}$ The demography seems to be too often blamed. the change of pension rules in early 1990s, in particular change in DB formulas resulted in impressing increase of replacement rates and contributed to the crisis. In average a pension benefit in Poland was worth of $78 \%$ of past wage of a pensioner/retiree in mid-1990s while the same relation in the Czech Republic and Hungary was respectively $44 \%$ and $60 \%$, and in the top seven OECD countries it amounted mere $38 \%$ (UNFE, 2000, p. 11).

${ }^{5}$ These are ratios for pension benefit aggregated (the first and the second pillars) provided OFEs' rate of return is $8 \%$ and wages rise at 3,5\% per annum, males are 37 years in employment and females are 33 years in employment (Gazeta Wyborcza, 4.03.2002)
} 
This reasoning makes a multi-pillar approach for the pension system attractive thanks to the suggestion of improving rather than deteriorating the outcome of the system as a whole 6 . The official concept of "security due to diversity" said that a multi-tier system created more security for would-be pensioners.

Alas, this reconstruction still leaves a question of having introduced OFEs unclear. Why apart from traditional PAYG and of a novelty of funded pensions another pillar or tier of mandatory funded pensions has been created? Of the two major changes which the reform brought, the shift from DB to DC formula was a rather direct device of improving the deficit of the public pension, thus alleviating the pressure on state budget deficit. This aspect of the reform was ultimately beneficial for the public finance (Łaski, 2010). The move to mandatory funding, however, had immediate adverse effect on the current deficits. The emergence of mandatory funded pillar due to transfers made to the OFEs must have aggravated the deficit of the public pension in ZUS-pillar and implied donations from the government budget, in consequence contributing to budget deficits. There was no budget surplus at that time to accommodate the negative consequences of current transfers. Why were open pension funds created then?

We skip here the way of arguing for mandatory funded pensions that had wide publicity ${ }^{7}$ in order to save space for two interesting hypotheses. In a nutshell, the premise of implicit debt as well as promise of economic growth played a role. The problem of implicit pension debt in fact can be translated into a question how to constrain financial as well as political and moral responsibility for the would-be pensioners' poverty. The premise of growth was strongly conditioned on growth of capital which was to be of help in stimulating a growth of GDP and, consequently, in increasing future budget revenues.

Implicit pension debt became explicit and transparent along with the introduction of individual accounts both in the FUS- and OFE-pillars. IPD is made by sum of liabilities which the universal pension system owes to pension savers with no regard to the form of pension financing (Rutecka, 2014, p. 5). With individual records, it became easy to be counted. With the emergence of OFEs, however, this sum could be exposed as clearly divided between publicly managed part and privately managed part of the universal system of old-age insurance ${ }^{8}$. Meaning of the change might be dividing both administration as well as responsibility for economic performance

${ }^{6}$ Another argument extensively used said that funding in the public pension system made pensions free from political abuse ("political risk"), to some extent at least.

${ }^{7}$ An extended arguing for mandatory funded pensions is well presented in Grabczan (1998).

${ }^{8}$ Respectively ca 2000 in 2014 and ca 300 in 2013 (Rutecka, 2014, p. 5). 
between public agency and private companies. More, while in the PAYG segment contributions loosing apparently at worth (e.g. due to inflation) seem politically unviable and therefore mechanisms of valorisation are set on, in capital segment this negative turn is a natural effect of change in market pricing and therefore it is much more bearable for the voters. Taking this economic-political perspective in the context of liabilities accumulated in the universal pension system, one can perceive OFEs as a device of shifting a part of responsibility for pensioners' well-being away from the state.

Still, such political gain from funding and privatisation in old-age insurance can be accomplished without making pension funding mandatory. As a matter of fact, this is the less developed country status which seemed to make the policy makers in Poland to move this step further.

The promise of growth (of financial markets at least) could not become true due to domestic savings which normally are low in Poland by international standards. Mandatory pension funding meant in fact using state apparatus to have relatively scarce households' savings to be transferred to financial markets. Introducing such a rule into the pension system secured consequent and steady transfers of capital (liquidity), which is a great attraction for actors in financial markets. The price to be paid immediately was the explicit budget gap due to the transfers to OFEs, which increased deficits of the publicly managed pension fund FUS and enforce donations from the government budget thus contributing to fiscal deficits.

The latter and consequent increase in the public debt became main reason for the reversal of expansion of mandatory pension funding in Poland. Contrary to the public pension deficit, which is no public debt, transfers of mandatory contributions to privately managed pension funds are regarded to increase the official debt (Rutecka, 2014, p. 6). According to this stance, confirmed with reference to the Polish case definitely by Eurostat in 2004, mandatory contributions to OFEs evenly with funded voluntary pension plans are regarded to be private money owned by fund-participants. Such accounting meant that transfers immanent to the second-pillar-operations made public debt in Poland as related to GDP higher by a couple of percentage points. After having broken the EU budget deficit bench-mark, with the burden of public debt approaching another EU limit the government represented by minister of finance John Vincent Rostowski said the cost of maintaining OFEs in terms of public debt was too high. According to the Ministry of Finance, if OFEs had never emerged the public debt would has been considerably lower as related to GDP. In 2012, for example, it would have amounted to $38 \%$ instead of $56 \%$, according to Eurostat accounting (MPPS\&MF, 2013, p. 25). That was the direct reason why the 
government scaled the open funds down since $2009^{9}$ and has radically changed the deal with the PTEs in 2013.

As argued above, it might be assumed that privatisation and funding attributed to OFEs would dilute implicit debt and the state's sole responsibility for yields of the system. Such speculations, if ever true, seem to get abandoned since the law of 2013 definitely has taken any implicit responsibility in this respect back from the OFEs; in mandatory segment of the pension insurance benefits are to be paid out by the public agency ZUS in practice on PAYG basis.

From the perspective of 2013 expectations regarding the question of growth of financial markets (and eventually of GDP) with OFEs as important actors turned out to be exaggerated either. As far as the volume of trade, success seems to be moderate and means for securities markets comfort rather than scales ${ }^{10}$. It is true that transferring contributions to the OFEs generate steady and certain inflow of funds into Warsaw Stock Exchange (GPW). However, OFEs' shares in trade in the GPW in 2010-2012 was a mere $6 \%$. The share in free float of stock was considerably higher $(26,5 \%$ in April 2013), however it appears disappointing when compared with early forecasts (70\% about/around 2005 - Rozłucki, 2001, ex. 6, p. 40). This means that liquidity in capital markets is due not that much to open pension funds but to individual and foreign investors. (Sławiński \& Tymoczko, 2013). Thus, institution of OFE after 15 years in operation seems to be no powerful vehicle transferring household savings to capital markets.

When speaking of the "growth effect" it is worth making a reference to a recently exploited argument that OFEs are relevant portfolio investors to non-financial companies. Open pension funds as stock holders seem to be important solely to big public companies registered in GPW. In the face of scarce capital and lack of domestic institutional investors with long-term perspective, they might be rather important for the privatisation process of big state-owned enterprises as new portfolio investors (Capital Strategy, 2013, p. 21). The introduction of open pension funds provided companies registered in Warsaw Stock Exchange with some additional equity. The OFEs purchased stock in ca 250 public companies being, however, limited by a ceiling to share-holdings amounting to $10 \%$ of equity of an individual company. The rest of ca 3000 thousand firms active in the national economy had no such chance (Oręziak, 2014b). Sometimes the OFEs are presented as share-holders who are ready for active governance (Capital Strategy,

\footnotetext{
${ }^{9}$ There were reductions in fees in 2009 as well as in portions contributed to the OFEs in 2011.

${ }^{10}$ It does not mean we ignore the aspect of development of new institutional arrangements due to OFEs which used to be exposed (Grabczan, 1998; Rozłucki 2001, p. 38) and is still regarded as relevant (Belka, 2011). However, we skip it here for reasons of space.
} 
2013, p. 21). This view, however, seems to be in contradiction to observation that OFEs change the structure of their portfolios quite often as compared to other investors (Rozłucki, 2001, p. 39). They are apparently loosely engaged in fates of the companies whose stock they hold. Consequently, reasoning that OFEs contributed to growth of domestic product along these lines seems to be risky.

The argumentation in this section said that the government as a major player was interested in alleviating implicit and explicit burden of deficits and debts in general government sector. Therefore, and for many other reasons which were ignored here, it has interest in a growth of economic performance; in Poland under transition to fully-fledged market economy especially development of financial markets as well as rules inviting for foreign capital inflows gained in prominence. At turn of the millenium OFEs could have been perceived as a helpful institutional device in these respects. However, the speculations turned out to be exaggerated, and explicit public debt issue became a first-hand reason for the recent policy reversal.

\section{Conclusions}

Poland was in the group of emerging market economies where at turn of the millennium paradigmatic pension reforms introduced an exceptional institutional device, namely mandatory funded pensions. The Polish government like others got exposed to persuasion of the World Bank and got inspired by argumentation for this very special form of pension financing. The rising implicit pension debt seemed to comprise a real threat then, and the issue of rising burden of responsibility for solvency of the public pension system was heavily exploited. The recent turnabout in Poland suggests that liabilities in the universal mandatory system which rise with no regard to the form of financing must be finally met by the state even if private managing companies have been invited into mandatory insurance. The argument of growth of financial markets (and eventually of GDP) with open pension funds as important actors seemed to be of special significance for an emerging market economy like Poland's. However, it lost in relevance as confronted with evidence of 15 years of the OFEs in operation. Although explicit budget deficits as well as consequent increase in public debt were obviously the immediate reasons for the reversal at turn of the first decades of XXI millennium, these lessons must be learned. Apart from the undesirable outcome of current debt accounting there were fundamental reasons of strategic nature for which government lost its interest in OFEs as an institutional (that is long-run) device. The current second wave of the 
pension reforms should be seen as result of shifts in the set of institutional and economic interests.

\section{References}

Barr, N. \& Diamond, P. (2009). Reforming pensions. CESifo working paper, No. 2523, January. http://dx.doi.org/10.1093/acprof:oso/9780195311303.001.0001.

Belka, M. (2011). Nie poszukujmy straconego czasu. Rzeczpospolita, 18 February.

Capital Strategy (2013). Wpływ OFE na rynek kapitałowy i rozwój gospodarki, 26.06.2013. Retrieved from http://www.efcongress.com/sites/default/files/ka walec-przezentacja_dla_ekf_-_2013-06-26.pdf (27 July 2014).

Grabczan, W. (1998). System otwartych funduszy emerytalnych jako element nowego systemu zabezpieczenia społecznego. Biuro Studiów i Ekspertyz. Informacja $\mathrm{nr}$ 642. Retrieved from http://biurose.sejm.gov.pl/teksty/i-642.htm (27.06.2014).

Impavido, G. \& Tower, I. (2009). How the Financial Crisis Affects Pensions and Insurance and Why the Impacts Matter. IMF Working Paper. IMF WP/9/151, July.

Pater, K.(2002). Interview. Rzeczpospolita, 15 October.

Kuczyński, P. (2011). Emeryci pod palmami. Przeglad, 6 February.

Łaski, K. (2010). Mity i rzeczywistość w ekonomii. Biuletyn PTE, 1.

Ministerstwo Pracy i Polityki Społecznej (MPPS) oraz Ministerstwo Finansów (MF) (2013). Przegląd funkcjonowania systemu emerytalnego. Bezpieczeństwo dzięki zrównoważeniu, June. Retrieved from http://www.mf.gov.pl/documents 1764034/1159300/201306 26_przeglad.pdf (13.07.2014).

Oręziak, L. (2014a). OFE. Katastrofa prywatyzacji emerytur w Polsce. Warszawa: Książka i Prasa.

Oręziak, L. (2014 b). Interview. Krytyka Polityczna, Retrieved from http://www.krytykapolityczna.pl/en/artykuly/gospodarka/20140403/oreziakofe-dzielo-sztuki-propagandy-medialnej (13.07.2014).

Rozłucki, W. (2001). Nowy system emerytalny w Polsce. BRE Bank-Case, No 57. Retrieved from http://www.nbportal.pl/library/pub_auto_B_0001/KAT_B 2150.PDF (17.07.2014).

Rutecka, J. (2014). System emerytalny po zmianach od 2014 roku. Teoria i praktyka ubezpieczeń w Polsce, 1(118).

Sarfati, H. \& Ghellab, Y. (2012). The political economy of pension reforms in times of global crisis: State unilateralism or social dialogue?. ILO Working Paper No. 37, Geneva, February.

Sławiński, A. \& Tymoczko, D. (2013). Emeryt może mieć więcej. Gazeta Wybor$c z a, 24$ June.

Szczurek, M. (2001). Interview. Rzeczpospolita, 9 November. 
64 Anna Zabkowicz

UNFE (Urząd Nadzoru nad Funduszami Emerytalnymi) (2000). Bezpieczeństwo dzięki konkurencji. Warszawa.

Ustawa z dn. 6 grudnia 2013 o zmianie niektórych ustaw w związku z określeniem zasad wypłaty emerytur ze środków zgromadzonych w otwartych funduszach emerytalnych (dz.U. 31 grudnia 2013 poz.1717). 